\title{
Sonic Hedgehog Protein
}

National Cancer Institute

\section{Source}

National Cancer Institute. Sonic Hedgehog Protein. NCI Thesaurus. Code C29962.

Sonic hedgehog protein (462 aa, $\sim 50 \mathrm{kDa}$ ) is encoded by the human $\mathrm{SHH}$ gene. This protein plays a role in embryonic pattern formation. 